\title{
DISTINGUISHING BIOLOGY FROM GEOLOGY IN SOFT-TISSUE PRESERVATION
}

\author{
JOHN A. CUNNINGHAM, ${ }^{1,2}$ PHILIP C. J. DONOGHUE, ${ }^{1}$ AND STEFAN BENGTSON² \\ ${ }^{1}$ School of Earth Sciences, University of Bristol, Bristol BS8 1RJ UK \\ $<$ John.Cunningham@bristol.ac.uk> \\ ${ }^{2}$ Department of Palaeobiology and Nordic Centre for Earth Evolution, Swedish Museum of Natural \\ History, 10405 Stockholm, Sweden
}

\begin{abstract}
Knowledge of evolutionary history is based extensively on relatively rare fossils that preserve soft tissues. These fossils record a much greater proportion of anatomy than would be known solely from mineralized remains and provide key data for testing evolutionary hypotheses in deep time. Ironically, however, exceptionally preserved fossils are often among the most contentious because they are difficult to interpret. This is because their morphology has invariably been affected by the processes of decay and diagenesis, meaning that it is often difficult to distinguish preserved biology from artifacts introduced by these processes. Here we describe how a range of analytical techniques can be used to tease apart mineralization that preserves biological structures from unrelated geological mineralization phases. This approach involves using a series of X-ray, ion, electron and laser beam techniques to characterize the texture and chemistry of the different phases so that they can be differentiated in material that is difficult to interpret. This approach is demonstrated using a case study of its application to the study of fossils from the Ediacaran Doushantuo Biota.
\end{abstract}

\section{INTRODUCTION}

The bulk of the animal fossil record consists of biomineralized remains such as bones, teeth, or shells. The preservation of soft tissues occurs only rarely in Konservat-Lagerstätten. These assemblages provide more complete data on the anatomy of ancient organisms and the diversity of their communities than can otherwise be obtained. In the Burgess Shale, for example, census counts show that $86 \%$ of species and $98 \%$ of individuals would not be preserved in shelly assemblages (Conway Morris, 1986). Inevitably, knowledge of evolutionary history depends heavily on fossils with soft-tissue preservation, which have provided critical insights into the most formative events in the history of life (Selden and Nudds, 2012). Fossils from Konservat-Lagerstätten preserve more of the organisms' anatomy and often reveal unique combinations of characters that provide data that are important for testing hypotheses of evolutionary relationships between groups (Briggs, 2003).

It is tempting to suppose that exceptionally preserved fossils have undergone virtually no decay and can be compared to living organisms as easily as living organisms can be compared one to another. This would be a mistake: these organisms have invariably undergone microbial decay, which often plays a key role in the authigenic mineralization of soft tissues (Briggs, 2003; Donoghue and Purnell, 2009). It is therefore vital to consider the process of microbial decay when interpreting exceptionally preserved fossils. Diagenetic processes are also important because they can introduce geological artifacts that can resemble anatomical structures despite having nothing to do with the biology of the organism (Bengtson and Budd, 2004). Difficulties in understanding the effects of these processes have meant that interpretations of exceptionally preserved fossils are often among the most contentious, with debates hinging on the identification of true biological anatomy and its distinction from pseudo-anatomical features.

In one such example, soft tissues including red blood cells have been reported from the bones of dinosaurs and other vertebrates from as long ago as the Cretaceous (Schweitzer et al., 2005, 2007; Schweitzer, 2011). This interpretation has not been accepted uncritically, with opponents arguing that the structures are better interpreted as a mixture of diagenetic iron oxide framboids and unmineralized biofilms (Martill and Unwin, 1997; 
Kaye et al., 2008), and challenging the molecular evidence used to support an origin as preserved soft tissue (Pevzner et al., 2008).

The Precambrian record is rife with cases where the biogenicity of putative fossils has been called into question. For example, filamentous structures from the $3.5 \mathrm{Ga}$ Apex Chert were initially accepted as probable photosynthetic cyanobacteria-like organisms (Schopf, 1993), but there has since been an intense debate over whether they are fossils at all (Brasier et al., 2002; Schopf et al., 2002; Schopf and Kudryavtsev, 2012, 2013; Marshall and Marshall, 2013; Pinti et al., 2013). The same issues have arisen in astrobiology, as exemplified by debates over the interpretation of the Martian meteorite ALH84001, which was initially interpreted as preserving fossil evidence of bacteria-like life (McKay et al., 1996). These claims have been hotly debated, with other workers proposing abiogenic processes that might be more likely to have formed the structures in question (Golden et al., 2000).

The primary reason that such debates persist is that it is difficult to disentangle preserved biological structures from the results of geological void-filling and overprinting. In reality, there is no clear distinction between fossilization and diagenesis, which are part of the same suite of processes. Moreover, most fossil material is likely to have a complex multiphase diagenetic and geological history that introduces further complications.

The processes of decay are as much about information gain as about information loss, preserving insights into the environments of death, decomposition, and diagenesis in microbial mineral fabrics and geochemistry (Briggs, 2003). Paleontologists, however, usually focus on the original biological anatomy of the organism, and some general predictions regarding the nature of early mineralization that preserves this anatomy versus later mineralization can be made. In principle, one might expect crystals that replicate labile soft tissue to form rapidly and therefore to be small and have random orientation. Mineralization that occurred later in diagenesis might be expected to grow slowly from a preexisting substrate and, therefore, be composed of large, well-formed crystals that have their long axes perpendicular to the substrate surface (Cunningham et al., 2012; Schiffbauer et al., 2012). This dichotomy is simplistic in that it tends to lump multiple phases of diagenetic and geological mineralization into a single category. Nevertheless, it is a distinction that has proven to be useful in the resolution of such debates, which require a careful analytical approach to characterize the anatomy and chemistry of the fossil and to distinguish the various phases of mineralization. Ideally, these phases should be characterized in uncontroversial material that either originates from the same deposit or is preserved in the same way before using this information to inform the interpretation of more contentious structures. A variety of X-ray, electron, ion, and laser-based techniques can and have been employed to obtain the necessary detailed insight. How such an integrated approach can operate is described by outlining some of the analytical techniques that can be applied (see Table 1 for a summary), then a case study is presented showing how some of these methods have been applied to the study of fossils from the Ediacaran Doushantuo Biota. This is a suitable example because many of areas of contention center on whether or not structures have been correctly interpreted as original anatomy. The list of potentially useful methods is obviously not exhaustive, but it constitutes a subset of available methods that are particularly informative with regard to fossil preservation. Paleontologists are encouraged not only to apply available analytical methods that seem appropriate, but also to stimulate and partake in the development and refinement of analytical technology by making it part of fossil investigations.

\section{ANALYTICAL TECHNIQUES}

\section{Backscattered electron imaging}

Imaging of backscattered electrons (BSE) is usually carried out on a scanning electron microscope (SEM) and enables the texture as well as aspects of the chemistry of a sample to be examined at high resolution (Orr et al., 2002). This technique captures beam electrons that are backscattered after interaction with the sample. The electrons in the beam are more likely to collide with atoms with higher atomic number and be elastically backscattered. As a result, the number of electrons reaching the detector is proportional to the atomic numbers and density of the sample material. This means that in a BSE image, the grayscale level reflects the average atomic number of materials proportionally, with brighter regions corresponding to materials of higher atomic number and darker regions 
TABLE 1.-Comparison of methods discussed in the text.

\begin{tabular}{|c|c|c|c|c|c|}
\hline Technique & Data Produced & $\begin{array}{c}\text { Used to } \\
\text { Characterize }\end{array}$ & $\begin{array}{l}2 \mathrm{D} / \\
3 \mathrm{D}\end{array}$ & $\begin{array}{c}\text { Size of } \\
\text { Specimen }\end{array}$ & Resolution \\
\hline $\begin{array}{l}\text { Backscattered } \\
\text { electron imaging } \\
(\mathrm{BSE})\end{array}$ & $\begin{array}{l}\text { Images with gray } \\
\text { level proportional to } \\
\text { atomic number }\end{array}$ & $\begin{array}{l}\text { Texture; some } \\
\text { chemical } \\
\text { information }\end{array}$ & $2 \mathrm{D}$ & $<100 \mathrm{~mm}$ & nm scale \\
\hline $\begin{array}{l}\text { Electron probe } \\
\text { microanalysis } \\
\text { (EPMA) }\end{array}$ & $\begin{array}{l}\text { Elemental maps or } \\
\text { quantitative analysis } \\
\text { of points }\end{array}$ & Chemistry & $2 \mathrm{D}$ & $<100 \mathrm{~mm}$ & $\begin{array}{l}\mu \mathrm{m} \text { scale } \\
\mathrm{nm} \text { scale }\end{array}$ \\
\hline $\begin{array}{l}\text { Cathodoluminescence } \\
\text { microscopy }\end{array}$ & $\begin{array}{l}\text { Maps of optical } \\
\text { luminescence }\end{array}$ & $\begin{array}{l}\text { Texture; some } \\
\text { chemical } \\
\text { information }\end{array}$ & $2 \mathrm{D}$ & $<100 \mathrm{~mm}$ & nm scale \\
\hline $\begin{array}{l}\text { Nano-Seconday Ion } \\
\text { Mass Spectrometry } \\
\text { (nano-SIMS) }\end{array}$ & $\begin{array}{l}\text { Chemical, } \\
\text { molecular, and } \\
\text { isotopic } \\
\text { composition }\end{array}$ & Chemistry & $2 \mathrm{D}$ & $<25 \mathrm{~mm}$ & nm scale \\
\hline $\begin{array}{l}\text { Times of Flight SIMS } \\
\text { (ToF-SIMS) }\end{array}$ & $\begin{array}{l}\text { Simultaneous } \\
\text { chemical, molecular, } \\
\text { and isotopic } \\
\text { analyses of } \\
\text { numerous } \\
\text { compositions }\end{array}$ & Chemistry & $2 \mathrm{D}$ & $<100 \mathrm{~mm}$ & $\mu \mathrm{m}$ scale \\
\hline $\begin{array}{l}\text { Synchrotron rapid } \\
\text { scanning X-ray } \\
\text { fluorescence } \\
\text { (SRS-XRF) }\end{array}$ & $\begin{array}{l}\text { Elemental maps and } \\
\text { quantitative analysis } \\
\text { of chemistry }\end{array}$ & Chemistry & $2 \mathrm{D}$ & $<1000 \mathrm{~mm}$ & $\mu \mathrm{m}$ scale \\
\hline Micro-CT & $\begin{array}{l}\text { Maps of x-ray } \\
\text { attenuation }\end{array}$ & $\begin{array}{l}\text { Texture; 3-D } \\
\text { structure }\end{array}$ & $3 \mathrm{D}$ & $<250 \mathrm{~mm}$ & $\mu \mathrm{m}$ scale \\
\hline $\begin{array}{l}\text { Synchrotron radiation } \\
\text { X-ray tomographic } \\
\text { microscopy (SRXTM) }\end{array}$ & $\begin{array}{l}\text { Maps of x-ray } \\
\text { attenuation }\end{array}$ & $\begin{array}{l}\text { Texture; 3-D } \\
\text { structure }\end{array}$ & $3 \mathrm{D}$ & $\begin{array}{l}<600 \mathrm{~mm} ; \\
\text { mm scale for } \\
\text { maximum } \\
\text { resolution }\end{array}$ & $\begin{array}{l}\mu \mathrm{m} \text { scale } \\
\mathrm{nm} \text { scale }\end{array}$ \\
\hline $\begin{array}{l}\text { Focused ion beam } \\
\text { tomography (FIB) }\end{array}$ & $\begin{array}{l}\text { Tomographic } \\
\text { datasets of multiple } \\
\text { BSE images }\end{array}$ & $\begin{array}{l}\text { Texture; can in } \\
\text { principle be } \\
\text { combined with } \\
\text { chemical } \\
\text { analysis }\end{array}$ & $3 \mathrm{D}$ & $<1 \mathrm{~mm}$ & nm scale \\
\hline $\begin{array}{l}\text { Scanning transmission } \\
\text { electron microscopy } \\
\text { (STEM) }\end{array}$ & $\begin{array}{l}\text { High-resolution } \\
\text { textural information }\end{array}$ & Texture & $2 \mathrm{D}$ & $<1 \mathrm{~mm}$ & nm scale \\
\hline Raman microscopy & $\begin{array}{l}\text { Spectra indicative of } \\
\text { molecular structure }\end{array}$ & Chemistry & $\begin{array}{l}2 \mathrm{D} / \\
3 \mathrm{D}\end{array}$ & $<1 \mathrm{~mm}$ & $\mu \mathrm{m}$ scale \\
\hline
\end{tabular}



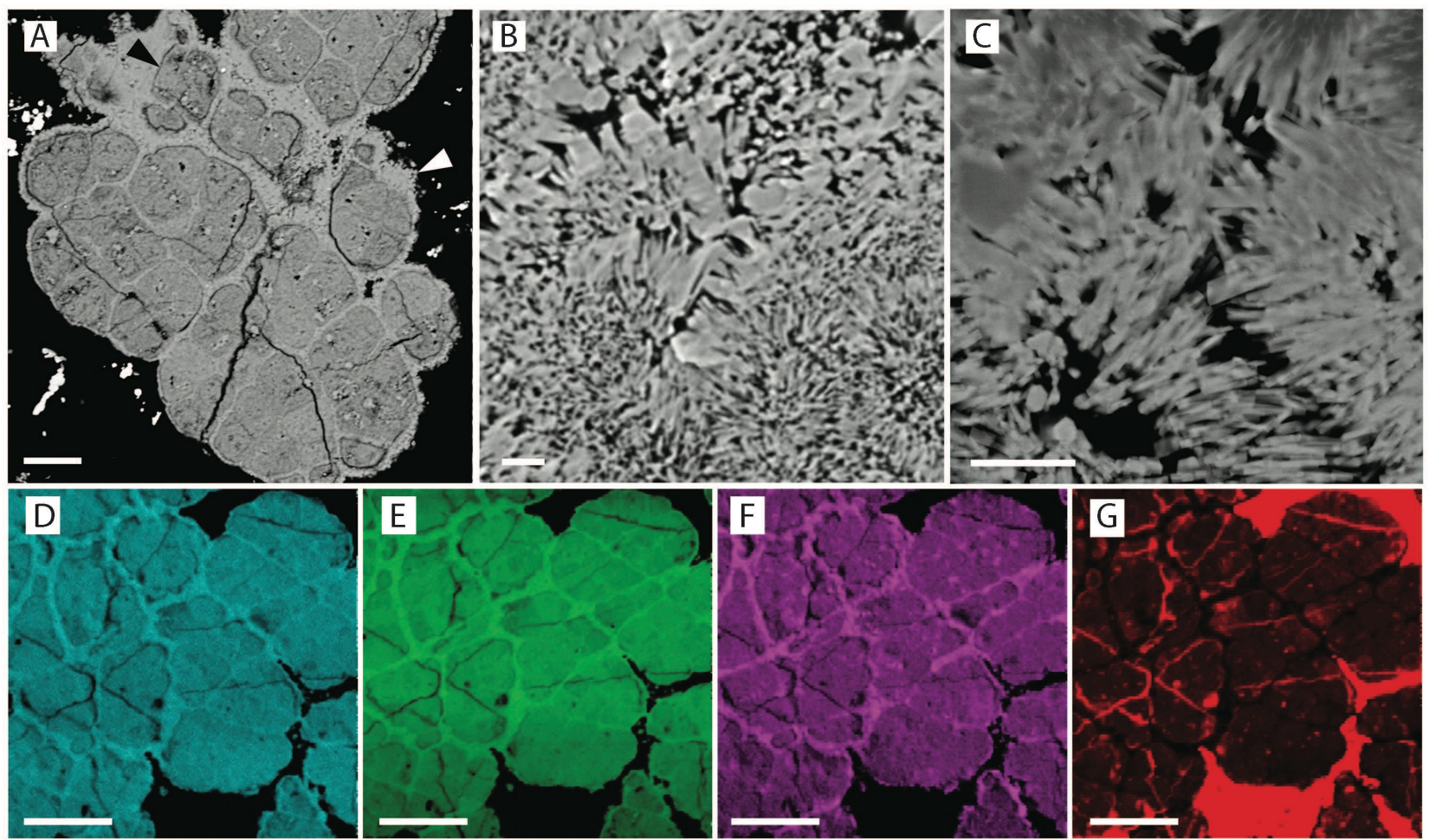

FIGURE 1.-Patterns of mineralization in the Ediacaran Doushantuo biota. A) BSE image of an alga; black arrow indicates low atomic number regions composed of nanoscale crystals that preserve algal anatomy, white arrow indicates encrusting diagenetic mineralization preserved in a high atomic number phase composed of micrometerscale crystals; Scale bar $=20 \mu \mathrm{m}$. B) BSE image of part of an embryo-like fossil that has been prepared by ion milling; Scale bar $=1 \mu \mathrm{m}$. C) STEM image of an embryo-like fossil; Scale bar $=1 \mu \mathrm{m}$. (D-G) EPMA images of an alga showing abundance maps of D) phosphorous, E) calcium, F) fluorine, G) carbon; very bright regions in the carbon map correspond to resin; scale bars $=50 \mu \mathrm{m}$. (A, D-G previously figured in Cunningham et al., 2012).

reflecting material of lower atomic number. BSE imaging can capture nanoscale resolution and provides qualitative chemical information. It has the disadvantage of requiring destructive cutting, grinding, and polishing preparation for optimal results, although it can be used on samples with topographic relief. In polished samples, this technique allows the texture, general chemistry, and pattern of crystal growth to be characterized at high resolution, allowing criteria for identifying different mineral phases to be established (Figs. 1A, B; 2A-C, F).

\section{Cathodoluminescence microscopy}

When electrons impact a luminescent material, they cause photons to be emitted. In cathodoluminescence microscopy, an optical detector captures these photons and a map of the optical activity is obtained. Differences in traceelement abundances across a sample affect the luminescence and provide valuable information about crystal growth and therefore about diagenetic processes (Scott and Collinson, 2003).
This technique can be carried out using a cathodoluminescence detector in an SEM or, alternatively, by using a specialized cathodoluminescence microscope. In either case, a polished surface is required.

\section{Electron probe microanalysis}

Electron probe microanalysis (EPMA) can either provide quantitative analysis of the chemical composition of a point on a specimen, or produce maps of the distribution of elements over the specimen, using a spot size as small as $1 \mu \mathrm{m}$ in standard thermionic source EPMA (Orr et al., 1998; Orr and Kearns, 2011) or even smaller in field emission gun EPMA systems (FEG-EPMA). In EPMA, an electron beam interacts with the sample, resulting in the emission of X-rays from the sample in the same way as SEM. These Xrays are captured by spectrometers, typically wavelength-dispersive X-ray spectrometers, which use the characteristic X-ray wavelengths emitted by different elements to measure their abundance. This method can provide detailed 

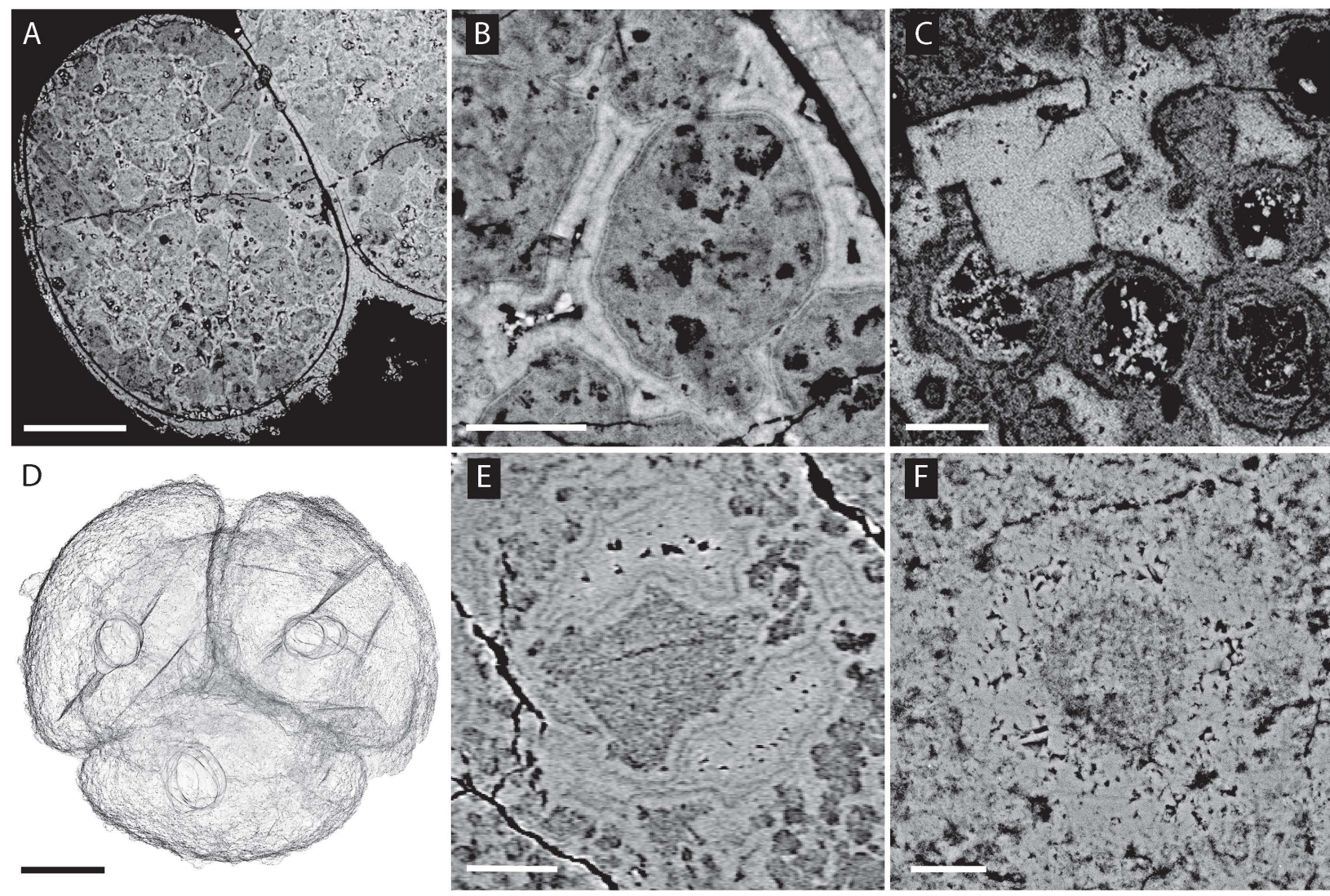

FIGURE 2.-Analysis of embryo-like fossils from the Ediacaran Doushantuo biota. A) BSE image of an embryolike fossil with preserved subcellular structures that have been interpreted as lipid droplets or yolk granules; scale bar $=100 \mu \mathrm{m}$; B) Detail of the same specimen as (A) showing diagenetic cements between these structures; scale bar $=20 \mu \mathrm{m}$. C) BSE image of an embryo-like specimen with hundreds of cells showing a T-shaped crystal that obliterates earlier structures; scale bar $=20 \mu \mathrm{m}$. D) SRXTM model of an embryo-like fossil that preserves rounded internal structures that have been interpreted as nuclei; scale bar $=100 \mu \mathrm{m}$. E) SRXTM image of a nucleus-like structure showing a low attenuation central region and a higher attenuation outer region with void-filling textures; Scale bar $=20 \mu \mathrm{m}$. F) BSE image of a nucleus-like structure; Scale bar $=20 \mu \mathrm{m}$. (A-C, E, F previously figured in Cunningham et al., 2012).

chemical information at a micrometer-scale resolution, but requires the destructive production of polished sections to produce optimal results. The use of EPMA analysis allows identification of chemical criteria for distinguishing between mineral phases (Fig. 1D-G).

\section{Secondary Ion Mass Spectrometry}

There are a number of related techniques that rely on Secondary Ion Mass Spectrometry (SIMS). In these techniques, ions (usually cesium or oxygen) are sputtered onto the surface of a specimen, causing ionized particles to be emitted.

These secondary ions can then be analyzed using a mass spectrometer in order to provide information about the chemical, molecular, and isotopic composition of the specimen. Using nanoSIMS (Wacey et al., 2010) or ion probe
(Xiao et al., 2010) analysis, it is possible to carry out analyses with higher resolution and sensitivity than is possible under EPMA. Time-of-Flight SIMS (ToF-SIMS) allows multiple compositions to be analyzed simultaneously (Lindgren et al., 2011; Orlando et al., 2013), in contrast to other techniques that are typically limited to approximately five spectrometers. These techniques are inherently destructive because they sputter material from the sample, and require destructive polishing for sample preparation.

\section{Synchrotron rapid-scanning X-ray fluorescence}

In synchrotron rapid-scanning $X$-ray fluorescence (SRS-XRF), an X-ray beam causes $\mathrm{X}$-ray fluorescence, which is then captured by a detector. Because each element emits a 
characteristic energy, the technique can be used to measure elemental abundance. The specimen is moved with respect to the X-ray beam to allow element maps to be produced. With a synchrotron source, elements can be detected in parts-permillion concentrations. This technique has the advantage in that large specimens that would not fit in an EPMA vacuum chamber can be analyzed rapidly at a resolution approaching that achieved in EPMA. It can be applied to flat specimens such as Mesozoic Plattenkalk material (Bergmann et al., 2010; Edwards et al., 2011; Manning et al., 2013) without preparation, although topography produces artifacts. Both EPMA and SRS-XRF can be used to produce chemical characterizations of fossil specimens. Higher resolutions can be achieved with EPMA, but SRS-XRF can provide better sensitivity.

\section{X-ray tomography}

X-ray tomography involves obtaining a series of X-ray images of a specimen at different orientations with respect to an X-ray beam. These images are then used to produce a series of parallel images that map X-ray attenuation in the specimen. Such images are usually presented as negatives, in which brightness correlates positively with X-ray attenuation. With the aid of software for computed tomography, this dataset can be sectioned virtually in any orientation and used to make 3-D images of the specimen that can be dissected digitally. Synchrotron Radiation Xray Tomographic Microscopy (SRXTM) has proven particularly valuable in the study of small specimens with soft-tissue preservation (Figs. 2D, E, 3B, C; Donoghue et al., 2006; Tafforeau et al., 2006). This approach uses an electron accelerator and storage ring to produce a high-brilliance, monochromatic (single wavelength), coherent Xray beam. This allows nondestructive 3-D analyses at sub-micrometer resolution with few scanning artifacts. Synchrotron-based phasecontrast imaging, which is based on X-ray refraction at material boundaries rather than attenuation, can provide improved contrast between materials with similar properties (Friis et al., 2007; Lak et al., 2008). Tomographic analyses are essential for characterizing internal structures in three dimensions, which can provide data on morphology and structure that can be critical in determining the identity of the specimens.

\section{Ion milling and focused ion beam tomography}

In ion milling, a beam of ions (usually argon) is fired at a specimen from an angle, sputtering material from the surface. This process results in a very smooth and flat surface, which is ideal for high-quality BSE and EPMA analysis and essential for techniques such as electron backscatter diffraction (EBSD), which determines the crystal structure of a specimen. A focused ion beam (FIB) setup also has a beam of ions (usually gallium) that can be used at high beam currents for this kind of milling. In dual beam systems, the ion beam is combined with an electron beam, meaning that a specimen can be milled and then imaged in situ using SEM. In FIB tomography this is carried out on a series of milled faces and used to produce a tomographic dataset of BSE images (Schiffbauer and Xiao, 2011; Wacey et al., 2012). This destructive technique can give very high-resolution data: the slices can be as little as $50 \mathrm{~nm}$ apart and each SEM image can have nanoscale resolution. In principle, chemical analyses can also be carried out in-situ, allowing chemical data to be incorporated into tomographic analyses, although there are still methodological difficulties associated with this in practice. Ion milling has been used to prepare samples for BSE analysis (Fig. 1B). FIB tomography has been successfully applied to Precambrian fossils (Schiffbauer and Xiao, 2009, 2011; Wacey et al., 2012).

\section{Scanning transmission electron microscopy}

Prior to scanning transmission electron microscopy (STEM) analysis, an ultra-thin slice is cut and lifted out of the specimen using a dual beam FIB system. A beam of electrons is then passed through this slice, producing interaction between the specimen and the beam. The electrons are captured after they have passed through the specimen and used to produce a very high-resolution image (resolution of $0.1 \mathrm{~nm}$ can be achieved). STEM differs from conventional TEM in that the beam is focused on a small spot that is scanned over the sample in a raster. This approach produces the highest resolution imaging, but cutting and lifting out the sample is very timeconsuming, and requires a skilled operator. Although the approach is destructive, the slices can be retained after analysis. STEM analysis allows crystals to be imaged at very high resolution, suggesting that it has great promise for characterizing very fine crystal textures (Fig. 1C).

\section{Laser Raman spectroscopy}

In Raman spectroscopy, monochromatic laser 

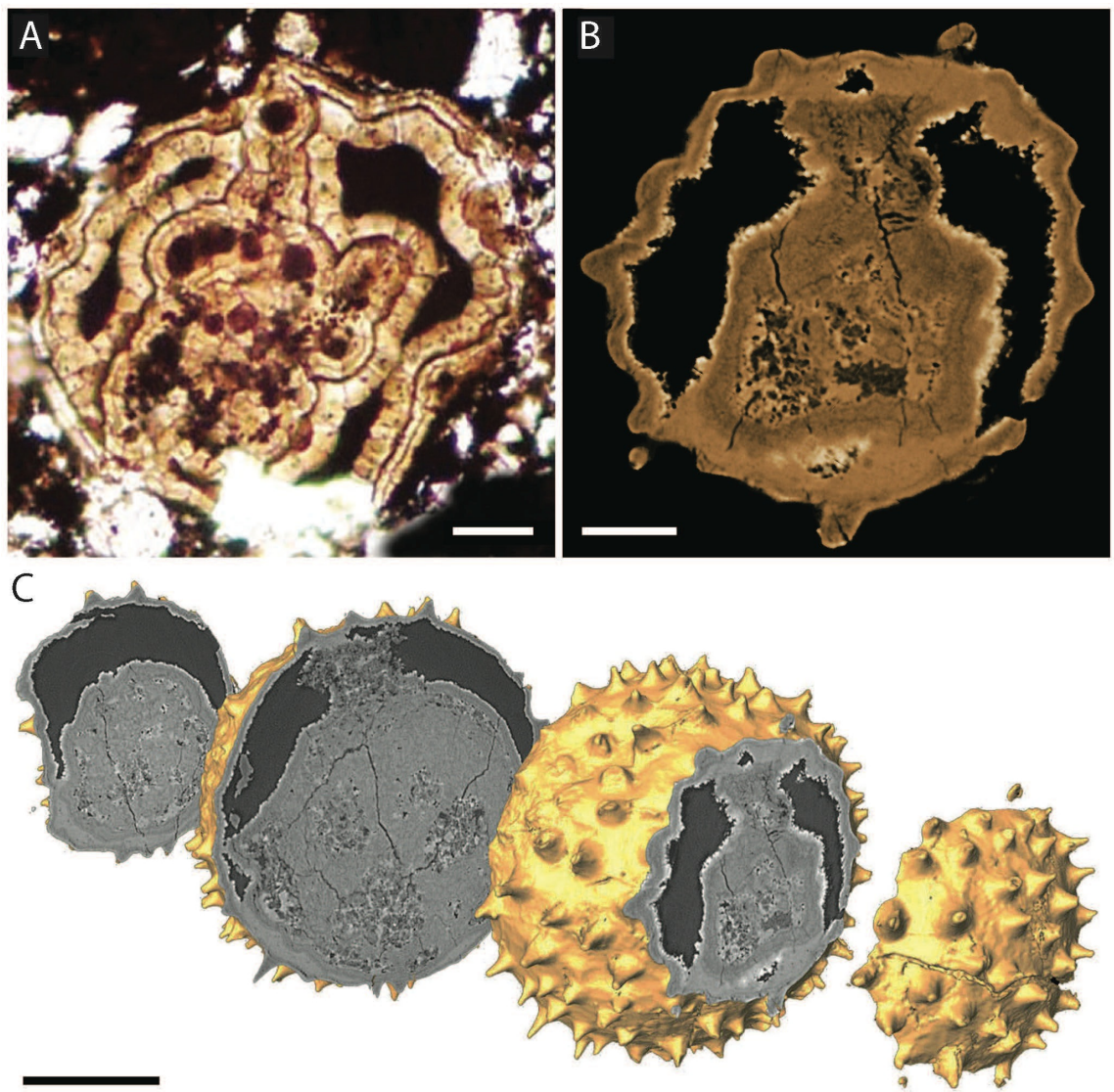

FigURE 3.-Vernanimalcula (A) and Vernanimalcula-like sections through an acritarch (B, C). A) Holotype of Vernanimalcula guizhouena Chen et al., 2004; scale bar $=20 \mu \mathrm{m}$. B) An SRXTM-based virtual section through an acritarch that appears bilaterally symmetrical and resembles specimens of Vernanimalcula; scale bar $=20 \mu \mathrm{m}$. C) Two-dimensional SRXTM sections at various intervals through the same specimen as (B), showing that bilateral symmetry is not persistent throughout the specimen; scale bar $=100 \mu \mathrm{m}$. (A) previously figured in Chen et al., 2004, (B, C) previously figured in Bengtson et al., 2012.

light interacts with molecules in the specimen resulting in scattered photons that have different energy to the incident photons. The energy of the scattered light gives information about the molecular structure of the sample. This technique has been used in paleontological studies aiming to distinguish organic kerogen from abiogenic graphite formed by geological processes (Brasier et al., 2002; Schopf et al., 2002; Schopf and Kudryavtsev, 2011). It has also been used to distinguish calcite from aragonite (Taylor et al., 2008), and to act as a proxy for diagenetic alteration of oxygen isotope composition (Thomas et al., 2011). Raman spectroscopy can be used in conjunction with confocal laser scanning microscopy (CLSM) to provide three-dimensional characterization of the morphology and molecular structure of a fossil specimen (Schopf and Kudryavtsev, 2011).

\section{CASE STUDY: DISCRIMINATING BIOLOGY FROM GEOLOGY IN THE DOUSHANTUO BIOTA}

The ca. 570 Ma Doushantuo Biota of southern China provides a rare snapshot of multicellular life in the Precambrian. It is famous for yielding a number of candidates for the oldest animal fossils in the record, including embryonic (Xiao et al., 1998), larval (Chen et al., 2000), and adult (Chen et al., 2004) forms. The interpretation of these fossils has been controversial (Xiao et al., 2000; Bengtson and Budd, 2004; Bailey et al., 2007; Huldtgren et al., 2011), but has important implications for the understanding of the timing and tempo of early metazoan evolution. The interpreted presence of animals, even bilaterians, in the Doushantuo Biota has been used to argue for an early diversification of metazoan phyla 
(Chen et al., 2004, 2009b). On the other hand, the interpreted absence of bilaterians from this wellsampled assemblage has been suggested as a good maximum constraint for the divergence of crownbilaterians for use in molecular clock analyses (Benton et al., 2009). Herein, we describe how an integrated approach using analytical techniques can provide the necessary data for interpreting the soft-bodied fossils from the Doushantuo Biota.

Following the description of fossils from the Doushantuo Biota as animal embryos (Xiao et al., 1998), a series of papers describing animal fossils from the deposit were published. These included reports of cnidarian embryos and larvae (Chen et al., 2000, 2002), anthozoan polyps (Chen et al., 2002), embryonic bilaterians (Chen et al., 2000, 2006, 2009a; Yin et al., 2013), and adult bilaterians (Chen et al., 2004). Many of these studies have been criticized for paying insufficient attention to diagenetic processes (Xiao et al., 2000; Bengtson, 2003; Conway Morris, 2003; Bengtson and Budd, 2004; Bengtson et al., 2012; Cunningham et al., 2012). The first challenge is to determine which aspects, if any, of the putative fossils in question represent preserved biology and which are geological mineralization. Second, the relationship of these mineral phases to the original biology of the organism must be understood: it is important to understand, for example, whether voids filled with geological mineralization reflect the morphology of original anatomical structures. These issues can be addressed by analyzing the chemistry and crystal growth of the structures in three dimensions (Cunningham et al., 2012; Schiffbauer et al., 2012), using a combination of analytical instruments.

Analysis of fossils from the biota such as algae (Fig. 1A, D-G) and acritarchs, which are uncontentious in terms of the distribution of preserved biological tissue and diagenetic artifacts, revealed two main styles of preservation in the deposit. Preserved soft tissue tends to be replicated by nanoscale crystals with random orientation, while diagenetic mineralization is characterized by micrometer-scale crystals with preferential orientation of the long axes and typical void filling textures (Cunningham et al., 2012; Schiffbauer et al., 2012).

The application of EPMA and SEM-based energy dispersive X-ray element maps to Doushantuo fossils has enabled chemical criteria for distinguishing different phases of mineralization that are combined with the crystallographic criteria discussed above (Cunningham et al., 2012; Schiffbauer et al., 2012). Regions with high atomic number correspond with high relative abundances of calcium, phosphorous, and fluorine, and low abundances of carbon (Fig. 1D-G). These regions are characteristic of late-stage diagenetic mineralization. Regions with low atomic number have the inverse pattern and tend to characterize preserved biological structures (Fig. 1D-G). In the case of Doushantuo, these chemical criteria are of secondary importance to the textural criteria, but they provide valuable supporting information and may prove critical in other Lagerstätten.

When controversial claims that have been made for Doushantuo fossils are revisited in the light of these findings, many of the interpretations are seen to be problematic. Features interpreted as specific anatomical structures are indistinguishable from diagenetic crusts in the same deposits, casting great doubt on these interpretations. For example, cnidarian and bilaterian gastrulae (Chen et al., 2000, 2002) more likely represent empty cysts that have been deformed and encrusted by diagenetic apatite cements (Xiao et al., 2000; Bengtson, 2003).

These analyses have enabled a clearer understanding of how the processes of decay, preservation, and diagenesis have altered the organisms preserved in this deposit. In embryolike specimens that preserve structures interpreted as lipid vesicles or yolk granules (Fig. 2A, B), these structures are very fine-grained with a low atomic number (Fig. 2B). This is comparable to the mineralization that is known to preserve soft tissue in Doushantuo algae (Fig. 1A). In order for these structures to become mineralized, the surrounding cytoplasm must first have been stabilized. This could have been by mineralization, although not in the form currently occupying these spaces. Alternatively, this stabilization could have been achieved by biofilms, which have been shown to replicate these regions (Raff et al., 2008). These spaces have been subsequently infilled by multiple phases of diagenetic apatite cements (Fig. 2B). The embryo-like specimens preserve structures that resemble cell membranes, but in the light of these analyses, they are better interpreted as encrustations on the exterior of the cell by diagenetic cement (Cunningham et al., 2012; Schiffbauer et al., 2012). In some cases, the original position of the membrane may be marked 
by a narrow void (Fig. 2A, B). Other embryo-like fossils from Doushantuo provide evidence that late diagenetic mineralization can also play a role in obliterating structures that formed earlier (Fig. 2C).

This kind of analysis has also been applied to structures proposed to be preserved nuclei (Hagadorn et al., 2006) that have the potential to provide phylogenetically informative data (Huldtgren et al., 2011). This interpretation has been challenged on the basis that these structures could have a diagenetic origin (Schiffbauer et al., 2012; Xiao et al., 2012). In order to study the nucleus-like structures in Doushantuo embryolike fossils, a specimen that had previously been imaged with SRXTM was ground to expose one of these structures (Cunningham et al., 2012). This allowed BSE analysis to be applied to these features, providing additional information and allowing the results from BSE and SRXTM to be contrasted (Fig. 2E, F). The resulting images are comparable because both are effectively related to the density of the sample. However, BSE has the advantage of producing higher resolution images than can be achieved routinely through tomography. On the other hand, SRXTM analyses have the advantages of being nondestructive and allowing 3-D characterization. Through this process, the nucleus-like structures were shown to be composed of two distinct zones of mineralization. The first zone was an outer region that was often crescent-shaped, and composed of relatively large (micrometer-scale) crystals with high atomic number, and exhibited typical voidfilling textures that characterize diagenetic mineralization (Fig. 2E, F; Cunningham et al., 2012; Schiffbauer et al., 2012). The second zone was composed of a globular inner body that had very fine nanoscale crystals and low atomic number (Fig. 2E, F; Cunningham et al., 2012). This inner structure has the characteristics of preserved soft tissue in Doushantuo fossils. It can be concluded that the outer part of the nucleuslike structures is void-filling diagenetic cement, whereas the inner part is likely replicated biological tissue that could represent the shrunken, degraded nucleus.

Another important criterion is the threedimensional morphology of the nucleus-like structures. This has been assessed through SRXTM analyses of Doushantuo fossils (Fig. 2D, E), which made it possible to identify specimens that had these structures, and to characterize and measure them in multiple specimens. From these analyses - which would have been impossible without a tomographic approach-it was established that the structures were consistent in occurrence, size, shape, position, and volumetric relationships (Huldtgren et al., 2011, 2012). Given this consistent occurrence, the structures are best interpreted as preserving voids created by decayed nuclei. While the structures clearly contain diagenetic cement (Huldtgren et al., 2011; Cunningham et al., 2012; Schiffbauer et al., 2012; Xiao et al., 2012), some factor must have produced the regular voids that these cements fill, and the best hypothesis is that these represent the original positions of nuclei (Huldtgren et al., 2012)

Failure to consider specimens in three dimensions can lead to misinterpretation. Fossils interpreted as anthozoan polyps (Chen et al., 2002) are more parsimoniously interpreted as sections through embryo-like fossils at various stages of decay when considered in this way. The example of Vernanimalcula illustrates this concept. Vernanimalcula was interpreted by Chen et al. (2004) as the tiny adult of a bilaterian animal from the Doushantuo Biota. It is known only from petrographic thin sections, from which Chen et al. (2004) identified putative bilaterian characters including paired coelomic cavities and a mouth, through gut, and anus (Fig. 3A). If truly a bilaterian, Vernanimalcula would represent the oldest bilaterian animal in the record. However, this report was quickly criticized by Bengtson and Budd (2004), who argued that many of the features that were essential to the bilaterian interpretation were better interpreted as artifacts of diagenetic mineralization. Despite this, Vernanimalcula has been widely cited in the literature as the oldest bilaterian animal (see Bengtson et al., 2012) and additional specimens have been reported (Petryshyn et al., 2013). However, the 3-D information on Doushantuo fossils gained from SRXTM analysis provides further evidence against a bilaterian interpretation (Bengtson et al., 2012). These data support Bengtson and Budd's (2004) contention that the Vernanimalcula specimens most likely represent chance sections through spherical envelopes containing degraded organic material. Bengtson et al. (2012) showed that sections through acritarchs and embryo-like specimens could indeed produce Vernanimalcula-like morphologies, even though they clearly did not have bilateral symmetry (Fig. 3B, C). This, in combination with the extreme similarity between diagenetic crusts from 
Doushantuo and structures interpreted as cellularly preserved anatomical features of Vernanimalcula, argues strongly against a bilaterian interpretation (Bengtson and Budd, 2004; Bengtson et al., 2012; Cunningham et al., 2012). When diagenetic processes are taken into consideration, there is no persuasive evidence for the presence of bilaterian animals - whether adults, embryos or larvae - in the Doushantuo Biota. This removes the fossil evidence for diversification of the group by this time and hints that the divergence may have occurred later. These findings highlight the importance of assessing which aspects of a fossil specimen reflect preserved anatomy and of integrating a range of analyses in order to address this question. These aspects are certainly not unique to the Doushantuo Biota.

\section{CONCLUSIONS}

Distinguishing preserved biology from geological artifact will always be difficult because there is no clear distinction between fossilization and diagenesis. As a result, gaining an appreciation of geological versus biological aspects of fossils is often only possible through the application of analytical techniques. When studying exceptionally fossilized biota, it is imperative that the optimal technique, or, more often, combination of techniques, is chosen for the problem in hand. This depends on the chemical and physical nature of the fossil as well as that of the host rock. The work on Doushantuo fossils shows that biology can be extracted from geological overprint with careful analytical work. Moreover, details of complex diagenetic and geological histories can also be studied, providing information about the post-depositional and later environment. It is essential that the processes of decay and diagenesis are taken into account when attempting to study specimens with soft-tissue preservation because failure to do so can lead to serious errors in interpretation. Ultimately, one should beware of studies that pay little heed to taphonomy.

\section{ACKNOWLEDGMENTS}

We are grateful to Federica Marone and Marco Stampanoni (Swiss Light Source), and Stuart Kearns and Tom Scott (Bristol) for advice and technical assistance. The manuscript was improved in the light of constructive suggestions by Jesse Broce and Jim Schiffbauer (Missouri), and Emma Locatelli (Yale).

\section{REFERENCES}

Bailey, J. V., S. B. Joye, K. M. Kalanetra, B. E. FLOOD, AND F.A. CORSETTI. 2007. Evidence of giant sulphur bacteria in Neoproterozoic phosphorites. Nature, 445:198-201.

BENGTSON, S. 2003. Tracing metazoan roots in the fossil record, p. 289-300. In A. Legakis, S. Sfenthourakis, R. Polymeni, and M. ThessalouLegaki (eds.), The New Panorama of Animal Evolution. Proceedings of the XVIII International Congress of Zoology, Athens, Greece, September, 2000. Pensoft Publishers, Sofia, Bulgaria.

BENGTSON, S., AND G. BudD. 2004. Comment on "Small bilaterian fossils from 40 to 55 million years before the Cambrian." Science, 306:1291a.

Bengtson, S., J. A. Cunningham, C. Yin, And P. C. J. Donoghue. 2012. A merciful death for the "earliest bilaterian," Vernanimalcula. Evolution \& Development, 14: 421-427.

Benton, M. J., P. C. J. Donoghue, And R. J. Asher. 2009. Calibrating and constraining the molecular clock, p. 35-86. In B. Hedges and S. Kumar (eds.), Dating the Tree of Life. Oxford University Press.

Bergmann, U., R. W. Morton, P. L. MANning, W. I. Sellers, S. Farrar, K. G. Huntley, R. A. WOGELIUS, AND P. LARSON. 2010. Archaeopteryx feathers and bone chemistry fully revealed via synchrotron imaging. Proceedings of the National Academy of Sciences of the United States of America, 107:9060-9065.

Brasier, M. D., O. R. Green, A. P. JePhCoAt, A. K. KLEPPE, M. J. VAN KRANENDONK, J. F. LindSAY, A. Steele, and N. V. Grassineau. 2002. Questioning the evidence for Earth's oldest fossils. Nature, 416:76-81.

BRIGGS, D. E. G. 2003. The role of decay and mineralization in the preservation of soft-bodied fossils. Annual Review of Earth and Planetary Sciences, 31:275-301.

Chen, J. Y., D. J. Bottjer, E. H. Davidson, S. Q. DORnBos, X. GaO, Y. H. YANG, C. W. LI, G. LI, X. Q. WanG, D. C. Xian, H. J. WU, Y. K. HwU, AND P. TAFFOREAU. 2006. Phosphatized polar lobe-forming embryos from the Precambrian of southwest China. Science, 312:1644-1646.

Chen, J. Y., D. J. BotTJER, E. H. DAvidson, G. LI, F. GaO, R. A. Cameron, M. G. Hadfield, D. C. Xian, P. Tafforeau, Q. J. Jia, H. SugiYama, AND R. TANG. 2009a. Phase contrast synchrotron X-ray microtomography of Ediacaran (Doushantuo) metazoan microfossils: Phylogenetic diversity and evolutionary implications. Precambrian Research, 173:191200.

Chen, J. Y., D. J. BotTJeR, G. Li, M. G. Hadfield, F. GaO, A. R. CAMERon, C. Y. Zhang, D. C. Xian, 
P. TAfForeau, X. LiaO, AND Z. J. Yin. 2009 b. Complex embryos displaying bilaterian characters from Precambrian Doushantuo phosphate deposits, Weng'an, Guizhou, China. Proceedings of the National Academy of Sciences of the United States of America, 106:19056-19060.

Chen, J. Y., D. J. Bottjer, P. Oliveri, S. Q. Dornbos, F. GaO, S. Ruffins, H. ChI, C. W. LI, AND E. H. DAVIDSON. 2004. Small bilaterian fossils from 40 to 55 million years before the Cambrian. Science, 305:218-222.

Chen, J. Y., P. Oliveri, F. GaO, S. Q. Dornbos, C. W. Li, D. J. BottJer, AND E. H. DAVIDSON. 2002. Precambrian animal life: Probable developmental and adult cnidarian forms from southwest China. Developmental Biology, 248:182-196.

Chen, J. Y., P. Oliveri, C. W. Li, G. Q. Zhou, F. GaO, J. W. Hagadorn, K. J. Peterson, AND E. H. DAVIDSON. 2000. Precambrian animal diversity: Putative phosphatized embryos from the Doushantuo Formation of China. Proceedings of the National Academy of Sciences of the United States of America, 97:4457-4462.

CONWAY MORRIS, S. 1986. The community structure of the Middle Cambrian Phyllopod Bed (Burgess Shale). Palaeontology, 29:423-467.

CONWAY MORRIS, S. 2003. The Cambrian "explosion" of metazoans and molecular biology: would Darwin be satisified? International Journal of Developmental Biology, 47:505-515.

Cunningham, J. A., C.-W. Thomas, S. Bengtson, S. L. Kearns, S. XiaO, F. Marone, M. Stampanoni, AND P. C. J. Donoghue. 2012. Distinguishing geology from biology in the Ediacaran Doushantuo biota relaxes constraints on the timing of the origins of bilaterians. Proceedings of the Royal Society B-Biological Sciences, 1737:2369-2376.

Donoghue, P. C. J., S. Bengtson, X. P. Dong, N. J. Gostling, T. Huldtgren, J. A. Cunningham, C. Yin, Z. Yue, F. Peng, And M. Stampanoni. 2006. Synchrotron X-ray tomographic microscopy of fossil embryos. Nature, 442:680-683.

Donoghue, P. C. J., AND M. A. Purnell. 2009. Distinguishing heat from light in debate over controversial fossils. BioEssays, 31:178-189.

Edwards, N. P., H. E. BARden, B. E. VAN DONGEN, P. L. MANning, P. L. LARSON, U. Bergmann, W. I. SEllers, AND R. A. Wogelius. 2011. Infrared mapping resolves soft tissue preservation in 50 million year-old reptile skin. Proceedings of the Royal Society B-Biological Sciences, 278:32093218.

Frits, E. M., P. R. Crane, K. R. Pedersen, S. Bengtson, P. C. J. Donoghue, G. W. Grimm, AND M. STAMPANONI. 2007. Phase-contrast X-ray microtomography links Cretaceous seeds with Gnetales and Bennettitales. Nature, 450:549-552.
Golden, D. C., D. W. Ming, C. S. Schwandt, R. V. Morris, S. V. YANG, AND G. E. LOFGREN. 2000. An experimental study on kinetically-driven precipitation of calcium-magnesium-iron carbonates from solution: Implications for the low-temperature formation of carbonates in Martian meteorite Allan Hills 84001. Meteoritics \& Planetary Science, 35:457-465.

Hagadorn, J. W., S. Xiao, P. C. J. Donoghue, S. Bengtson, N. J. Gostling, M. Pawlowska, E. C. RAFF, R. A. RAFF, F. R. TURNER, Y. CHONGYU, C. Zhou, X. Yuan, M. B. MCFeEly, M. StampanONi, AND K. H. NeALSON. 2006. Cellular and subcellular structure of Neoproterozoic animal embryos. Science, 314:291-294.

Huldtgren, T., J. A. Cunningham, C. Yin, M. Stampanoni, F. Marone, P. C. J. Donoghue, AND S. BENGTSON. 2011. Fossilized nuclei and germination structures identify Ediacaran 'animal embryos' as encysting protists. Science, 334:16961699.

Huldtgren, T., J. A. Cunningham, C. Yin, M. Stampanoni, F. Marone, P. C. J. Donoghue, AND S. Bengtson. 2012. Response to Comment on "Fossilized nuclei and germination structures identify Ediacaran 'animal embryos' as encysting protists." Science, 335:1169

Kaye, T. G., G. Gaugler, And Z. SAwlowwicz. 2008. Dinosaurian soft tissues interpreted as bacterial biofilms. PLoS ONE, 3:e2808: doi: 10.1371/journal.pone.0002808

Lak, M., D. Neraudeau, A. Nel, P. Cloetens, V. PERrichot, AND P. TAFFOREAU. 2008. Phase contrast X-ray synchrotron imaging: Opening access to fossil inclusions in opaque amber. Microscopy and Microanalysis, 14:251-259.

Lindgren, J., P. Uvdal, P. SJövall, D. E. Nilsson, A. Engdahl, B. Pagh Schultz, And V. Thiel. 2011. Molecular preservation of the pigment melanin in fossil melanosomes. Nature Communications, 3:824. doi:10.1038/ ncomms 1819

Manning, P. L., N. P. EdWARds,R. A. Wogelius, U. Bergmann, H. E. BARden, P. L. LARSON, D. SCHWARZ-Wings, V. M. EgERTON, D. SOKARAS, R. A. MORI, AND W. I. SEllers. 2013. Synchrotron-based chemical imaging reveals plumage patterns in a 150 million year old early bird. Journal of Analytical Atomic Spectrometry, 28:1024-1030.

Marshall, A. O., AND C. P. Marshall. 2013. Comment on "Biogenicity of Earth's earliest fossils: a resolution of the controversy" by J. W. Schopf and A. B. Kudryavtsev, Gondwana Research, Volume 22, Issue 3-4, Pages 761-777. Gondwana Research, 23:1654-1655.

Martill, D. M., AND D. M. UnwIN. 1997. Small spheres in fossil bones: Blood corpuscles or 
diagenetic products? Palaeontology, 40:619-624.

McKay, D. S., E. K. GibSON, K. L. ThOMAS-KePRTA, H. Vali, C. S. RomaneK, S. J. Clemett, X. D. F Chillier, C. R. MAechling, AND R. N. Zare. 1996. Search for past life on Mars: Possible relic biogenic activity in Martian meteorite ALH84001. Science, 273:924-930.

Orlando, L., A. Ginolhac, G. J. Zhang, D. Froese, A. Albrechtsen, M. Stiller, M. Schubert, E. Cappellini, B. Petersen, I. Moltke, P. L. F. Johnson, M. Fumagalli, J. T. Vilstrup, M. Raghavan, T. Korneliussen, A. S. Malaspinas, J. Vogt, D. SzklarczyK, C. D. Kelstrup, J. Vinther, A. Dolocan, J. Stenderup, A. M. V. VelazQuez, J. CAhill, M. Rasmussen, X. L. Wang, J. M. Min, G. D. Zazula, A. Seguin-Orlando, C. Mortensen, K. Magnussen, J. F. ThOMPSON, J. Weinstock, K. Gregersen, K. H. Roed, V. EisenmanN, C. J. Rubin, D. C. Miller, D. F. AntczaK, M. F. Bertelsen, S. Brunak, K. A. S. Al-Rasheid, O. Ryder, L. ANDERsSOn, J. Mundy, A. Krogh, M. T. P. GILBERT, K. KJAER, T. SiCHERITZ-PONTEN, L. J. Jensen, J. V. Olsen, M. Hofreiter, R. Nielsen, B. Shapiro, J. Wang, And E. WILLERSLEV. 2013. Recalibrating Equus evolution using the genome sequence of an early Middle Pleistocene horse. Nature, 499:74-78.

OrR, P. J., D. E. G. Briggs, And S. L. KeArns. 1998. Cambrian Burgess Shale animals replicated in clay minerals. Science, 281:1173-1175.

OrR, P. J., AND S. L. KEARNS. 2011. X-ray microanalysis of Burgess Shale and similarly preserved fossils, p. 271-299. In M. Laflamme, J. D. Schiffbauer, and S. Q. Dornbos (eds.), Quantifying the Evolution of Early Life. Topics in Geobiology 36, Springer, Dordrecht.

OrR, P. J., S. L. KeARnS, AND D. E. G. Briggs. 2002. Backscattered electron imaging of fossils exceptionally-preserved as organic compressions. PALAIOS, 17:110-117.

Petryshyn, V. A., D. J. Bottjer, J.-Y. Chen, And F. GAO. 2013. Petrographic analysis of new specimens of the putative microfossil Vernanimalcula guizhouena (Doushantuo Formation, South China). Precambrian Research, 225:58-66.

PevzNer, P. A., S. KIM, AND J. NG. 2008. Comment on "Protein sequences from Mastodon and Tyrannosaurus rex revealed by mass spectrometry." Science, 321:1040.

Pinti, D. L., R. Mineau, And V. Clement. 2013. Comment on "Biogenicity of Earth's earliest fossils: a resolution of the controversy" by J. William Schopf and Anatoliy B. Kudryavtsev, Gondwana Research 22 (2012), 761-771. Gondwana Research, 23:1652-1653.

RafF, E. C., K. L. Schollaert, D. E. Nelson, P. C. J.
Donoghue, C. W. Thomas, F. R. Turner, B. D. Stein, X. Dong, S. Bengtson, T. Huldtgren, M. Stampanoni, C. Y. Yin, and R. A. RafF. 2008. Embryo fossilization is a biological process mediated by microbial biofilms. Proceedings of the National Academy of Sciences of the United States of America, 105:19360-19365.

SchiffBauer, J. D., AND S. H. XiAO. 2009. Novel application of Focused Ion Beam Electron Microscopy (FIB-EM) in preparation and analysis of microfossil ultrastructures: A new view of complexity in early Eukaryotic organisms. PALAIOS, 24:616-626.

SCHIFFBAUER, J. D., AND S. XIAO. 2011. Paleobiological applications of focused ion beam electron microscopy (FIB-EM): an ultrastructural approach to the (micro)fossil record, p. 321-354. In M. Laflamme, J. D. Schiffbauer, and S. Q. Dornbos (eds.), Quantifying the Evolution of Early Life. Topics in Geobiology 36, Springer, Dordrecht.

SchiffBaUer, J. D., S. H. XIAO, K. SEN Sharma, AND G. WANG. 2012. The origin of intracellular structures in Ediacaran metazoan embryos. Geology, 40:223-226.

SCHOPF, J. W. 1993. Microfossils of the Early Archean Apex Chert: new evidence of the antiquity of life. Science, 260:640-646.

Schopf, J. W., AND A. B. KudryavtseV. 2011. Confocal laser scanning microscopy and Raman (and fluorescence) spectroscopic imagery of permineralized Cambrian and Neoproterozoic fossils, p. 241-270. In M. Laflamme, J. D. Schiffbauer, and S. Q. Dornbos (eds.), Quantifying the Evolution of Early Life. Topics in Geobiology 36, Springer, Dordrecht.

Schopf, J. W., AND A. B. KudRYAVTSEV. 2012. Biogenicity of Earth's earliest fossils: A resolution of the controversy. Gondwana Research, 22:761771.

Schopf, J. W., AND A. B. KudRYAVTSEY. 2013. Reply to the comments of D. L. Pinti, R. Mineau and V. Clement, and of A. O. Marshall and C. P. Marshall on "Biogenicity of Earth's earliest fossils: A resolution of the controversy" by J. William Schopf and Anatoliy B. Kudryavtsev, Gondwana Research 22 (2012), 761-77. Gondwana Research, 23:1656-1658.

Schopf, J. W., A. B. Kudryavtsev, D. G. Agresti, T. J. WDOWIAK, AND A. D. CZAJA. 2002. LaserRaman imagery of Earth's earliest fossils. Nature, 416:73-76.

SCHWEITZER, M. H. 2011. Soft tissue preservation in terrestrial Mesozoic vertebrates. Annual Review of Earth and Planetary Sciences, 39:187-216.

Schweitzer, M. H., Z. Suo, R. Avci, J. M. AsAra, M. A. Allen, F. T. Arce, And J. R. Horner. 2007. Analyses of soft tissue from Tyrannosaurus 
rex suggest the presence of protein. Science, 316:277-280.

SCHWEITZER, M. H., J. L. WitTMEYER, J. R. HoRnER, AND J. K. TOPORSKI. 2005. Soft-tissue vessels and cellular preservation in Tyrannosaurus rex. Science, 307:1952-1955.

ScotT, A. C., AND M. E. Collinson. 2003. Nondestructive multiple approaches to interpret the preservation of plant fossils: implications for calcium-rich permineralizations. Journal of the Geological Society, 160:857-862.

SEldEN, P., AND J. R. NudDS. 2012. Evolution of Fossil Ecosystems (Second Edition). Academic Press, London.

Tafforeau, P., R. Boistel, E. Boller, A. Bravin, M. Brunet, Y. Chaimanee, P. Cloetens, M. Feist, J. Hoszowska, J. J. JAeger, R. F. KAY, V. Lazzari, L. MarivauX, A. Nel, C. Nemoz, X. Thibault, P. Vignaud, AND S. Zabler. 2006. Applications of X-ray synchrotron microtomography for non-destructive 3D studies of paleontological specimens. Applied Physics AMaterials Science \& Processing, 83:195-202.

Taylor, P. D., A. B. Kudryavtsev, And J. W. SCHOPF. 2008. Calcite and aragonite distributions in the skeletons of bimineralic bryozoans as revealed by Raman spectroscopy. Invertebrate Biology, 127:87-97.

Thomas, D. B., C. M. McGoverin, R. E. Fordyce, R. D. FreW, AND K. C. Gordon. 2011. Raman spectroscopy of fossil bioapatite-A proxy for diagenetic alteration of the oxygen isotope composition. Palaeogeography, Palaeoclimatology, Palaeoecology, 310:62-70.

Wacey, D., D. Gleeson, AND M. R. Kilburn. 2010. Microbialite taphonomy and biogenicity: new insights from NanoSIMS. Geobiology, 8:403-416.

Wacey, D., S. Menon, L. Green, D. Gerstmann, C. Kong, N. Mcloughlin, M. SAunders, And M. BRASIER. 2012. Taphonomy of very ancient microfossils from the $\sim 3400$ Ma Strelley Pool Formation and $\sim 1900$ Ma Gunflint Formation: New insights using a focused ion beam. Precambrian Research, 220:234-250.

XiaO, S. H., A. H. Knoll, J. D. Schiffbauer, C. M. ZHOU, AND X. L. YUAN. 2012. Comment on "Fossilized nuclei and germination structures identify Ediacaran 'animal embryos' as encysting protists." Science, 335:1169.

XiaO, S. H., J. D. Schiffbauer, K. A. McFadden, AND J. HunTER. 2010. Petrographic and SIMS pyrite sulfur isotope analyses of Ediacaran chert nodules: Implications for microbial processes in pyrite rim formation, silicification, and exceptional fossil preservation. Earth and Planetary Science Letters, 297:481-495.

XiaO, S. H., X. L. Yuan, and A. H. KnOll. 2000. Eumetazoan fossils in terminal Proterozoic phosphorites? Proceedings of the National Academy of Sciences of the United States of America, 97:13684-13689.

XiaO, S. H., Y. Zhang, AND A. H. KnOll. 1998. Three-dimensional preservation of algae and animal embryos in a Neoproterozoic phosphorite. Nature, 391:553-558.

Yin, Z., M. Zhu, P. Tafforeau, J.-Y. Chen, P. LiU, AND G. LI. 2013. Early embryogenesis of potential bilaterian animals with polar lobe formation from the Ediacaran Weng'an Biota, South China. Precambrian Research, 225:44-57. 
The Paleontological Society PaPers, V. 20 